\section{Dr. J. T. Edwards}

Dr. J. T. Enwards, who died on November 7, made noteworthy contributions to veterinary science. $\mathrm{He}$ had a brilliant scholastic career, and when he qualified in 1911 was undoubtedly regarded by many of his seniors as the best veterinary graduate of his generation.

After study at the Pasteur Institute, Paris, under a three-years research scholarship, study in Germany having been prevented by the First World War, he served for two years in France with the Army Veterinary Corps, and was mentioned in dispatches. Some years of research under the late Sir John M'Fadyean followed, and he was then appointed to the new chair of veterinary hygiene at the Royal Veterinary College, London, in 1920. He received the degree of D.Sc.(London) in 1926, the title of his thesis being "Tho Chemotherapy of Surra in Horses and Cattle in India".

In 1921, Edwards was appointed director of the Imperial Bacteriological Laboratory (later Imperial Institute of Veterinary Research), Muktesar, India, the most important veterinary appointment in that country, and for the next eight years produced work of remarkable value, carrying out intensive investigations on wide range of animal disease subjects.

His research work on rinderpest proved to be of a very high order, although its full value was not universally recognized until after an interval of nearly twenty years. The results of this investigation were not published in detail at the time because of preoccupation with current work.

Rinderpest immunization had tended to be hazardous, partly because of the danger of intercurrent infection with piroplasmosis and certain other diseases precipitated by the body reaction to the vaccine, and partly because of varying susceptibility of cattle to the virus. Edwards conceived the idea of adapting the virus to rabbits as unnatural hosts on the basis of the work of Jenner and of Pasteur, in the hope of obtaining a living virus which would immunize without producing the disease, and he laboriously set out on what appeared to be a hopeless task. He achieved success, but not final success. At the peak of the work his rabbit stock was wiped out by bacterial infection. In India there was no stock of rabbits to replace them and he turned his attention to the goat, again in the hope of producing a suitably modified virus. He succeeded, and his goat-adapted strain of the rinderpest virus has proved to be a highly efficient live vaccine for the immunization of Indian cattle, and it has been used systematically in India ever since with great success. After suitable modification for cattle in Africa, it has proved of great value also in that continent.

Japanese workers produced a rabbit-adapted rinderpest virus in the nineteen-thirties and acknowledged the inspiration of Edwards's work. Their rabbit strain has since proved to be immensely valuable. So Edwards's work on the rabbit-adapted and the goat-adapted strains of the rinderpest virus has stood the test of time and provided outstanding developments in all work on this terrible disease of cattle. Now, for the first time, and entirely as a result of these developments, leaders at international conferences are speaking hopefully of the eradication of rinderpest from continents.

There has been a further development of this work. In the United States in recent years the swine-fever virus has similarly been adapted to rabbits, and the modified strain has been used with great success for the immunization of pigs. American workers have acknowledged the lead provided in this work by the results Edwards achieved with the rinderpest virus. At the present time this new swinefever vaccine is regarded as the most important advance made in the study of that disease, and great advantages are anticipated from its use.

In 1929 Edwards returned to England and joined the staff of the Foot and Mouth Disease Research Committee, working first at the Lister Institute and later at the Pirbright laboratory.

Edwards published many papers on a variety of subjects, and a number of his contributions will maintain their importance for years to come. $\mathrm{He}$ was active over a wide range of veterinary activities in Britain during the past two decades and was very highly respected in his profession.

He was awarded honours by his profession, and when on deputation to the Egyptian Government was awarded the Order of the Nile (3rd Class) by the late King of Egypt. $\mathrm{He}_{\theta}$ was a past president of the Section of Comparative Medicine of the Royal Society of Medicine. $\mathrm{He}$ was a member of the Councils of both the Royal College of Veterinary Surgeons and of the British Veterinary Association.

During 1916-21 he edited the Tropical Veterinary Bulletin, and, after the death of Sir John M'Fadyean, he became one of the editorial board formed to continue the Journal of Comparative Pathology and Therapeutics.

Edwards was deeply interested in psychology and in animal behaviour. In recent years he devoted much of his literary activities to veterinary history, on which he published important contributions in the Veterinary Record and elsewhere.

W. A. Poor

\section{Prof. Johan Böhm}

THE newly organized Czechoslovak Academy of Science and the Research Institute of Organic Syntheses have suffered a great loss by the decease of the distinguished physical chemist, Prof. J. Böhm, on November 27, 1952. Born in 1895 in Budðjovice, Southern Bohemia, Böhm studied at the German Institute of Technology and at the University of Prague, and also worked in the Kaiser Wilhelm Institut für physikalische Chemie, Berlin. At that time this Institution was at its height under the leadership of Prof. F. Haber, with collaborators such as v. Hevesy, Willstätter, Zsigmondi, Freundlich and Polányi. Böhm graduated at the period of the successful start of $\mathrm{X}$-ray applications to structural analysis of crystals and himself added much to the perfection of this method. His first work elucidated the binding of water in zeoliths, and later research solved the structures of several metallic hydroxides, especially of $\gamma$-AlO.OH, which modification has been called 'böhmite' in his honour. 'This was in 1926, in which Böhm also investigated the strongly exothermic spontaneous recrystallization of finely powdered silver and antimony. At the same time, Böhm constructed with Weissenberger the well-known X-ray goniometer.

Soon after that, Böhm went with v. Hevesy to Niels Bohr's laboratory; but when v. Hevesy was invited by the University of Freiburg-im .Breisgau to fit up the Institute of Physical Chemistry he took Böhm with him. Böhm remained in Freiburg until 1934, first building and installing X-ray laboratories, 
introducing there his new 'secondary' method of structural X-ray analysis, and, as research director in physical chemistry, practical classes in photochemistry and colloids. He became assistant professor in 1934.

However, the Nazi era altered Böhm's scientific life. Profs. v. Hevesy and Böhm had to leave Germany. The latter, who always kept his Czechoslovak nationality, accepted the invitation of the Czechoslovak government to the chair of physical chemistry at the German University in Prague. During the German occupation of Prague, Böhm was again subjected to political pressuro; but he never joined the Nazi party, and continued to help his numerous Czech friends in their scientific work in a fearless manner.

Böhm's own research work in the war years concerned again $\mathrm{X}$-ray investigations and photography; but it remains mostly unpublished, as his pupils left Prague in the critical year 1945. When conditions settled down again, Böhm was employed as a research chemist in the national enterprise Rybitvi near Prague, and remained there in spite of several offers of a post as a university teacher. The many sufferings he had sustained had deprived him of self-confidence. At last he consented to work in the physico-chemical laboratory of the Czechoslovak Academy of Science and was one of the first of the nominated corresponding members of that institution.

Prof. Böhm possessed not only a great capacity for experimental work, but also a unique strength of character. His philosophical attitude and faith in social justice guided him safely through national and political struggles. His great modesty, self-denial and willingness to help others led to over-work, which destroyed the hopes of his friends just when he had returned to academic research.

$$
\text { J. HeYROVSKÝ }
$$

\section{Prof. Otto Pratje}

Prof. Otto Pratje, who was both head of the marine geological section of the German Hydrographic Institute and lecturer in geology at the University of Hamburg, died on December 11, at the age of sixty-two.

Although originally committed to a commercial career, Pratje studied geology concurrently for several years in Britain and Swedon. After the First World War, he decided that his profession was not to his taste, and took his doctor's degree at Freiburg in 1921 under Deecke. During the ensuing period he worked as an assistant at the University of Freiburg on the marine sediments of the Continent of Europe.

The course of his life's work was, however, decided by his move to Königsberg, where he acted as a university assistant and lecturer during 1923-27. His chief study was the geology of the sea-bed, and it was to this that he owed his participation in the Meteor Atlantic expedition during 1925-26. In 1937 he was appointed to establish and direct the marine geological section of the Deutsche Seewarte at Hamburg. After the Second World War he joined its successor, the German Hydrographic Institute, and also became a member of the lecturing staff of the University of Hamburg.

The abundance of Prof. Pratje's publications bears witness to his diligence and fertile mind, and will bo a lasting monument to him. While his earlier papers were devoted to the geological and palæontological problems of the Continent, in particular those of the
Jurassic formations of south-west Germany, marine geology came more and more into the foreground during the Königsberg period. At first he wrote several papers on Heligoland, including the wellknown geological guide, but then turned completely to the sea-bed. He also made a systematic collection of bottom samples during many research voyages. In addition to a number of papers on the formation of sediments in the North Sea and the Baltic, we owe to him what are believed to be the most detailed geological charts of these seas yet compiled. Parallel with this work, Pratje carried out the laborious evaluation of the bottom samples collected during tho Meteor expedition, of which two parts have appeared in print. Unfortunately, his official duties, combined with war-time and post-war conditions, prevented the completion of this work. Finally, in an extensive paper in the "Handbuch der Naturwissenschaften", he described the techniques and methods of collecting and evaluating samples from the ocean bottom, supplementing it, in the "Jahrbuch der Geographischen Gesellschaft", with references to his most recent experience.

Prof. Pratje laboured much and achieved much, though some of his work was incomplete when he died. What remains is the memory of a kindiy man who was always ready to collaborate, in whose presence no harsh word was ever heard, and who knew how to suffer hard blows with a quiet mind.

\section{Prof. Francesco Vercelli}

WE regret to report that the distinguished Italian geophysicist, Prof. F. Vercelli, director of the Geophysical Observatory and of the Thalassographical Institute of 'Trieste, died, at the age of sixty-nine, on November 24.

Prof. Vercelli contributed to rescarch in several branches of geophysics. In oceanography he investigated the transmission of solar radiation through sea and lake water and the effects of wind and pressure variations on the tides, and led oceanographic expeditions in Italian naval vessels to various parts of the Mediterranean and Red Sea. He devised a method of harmonic analysis and applied it to the prediction of pressure changes. He sought for the sunspot cycle in tree-ring records. His earliest geophysical work was concerned with temperature in tunnels in connexion with the construction of the Simplon tunnel; later, he founded a seismological station at Trieste and took part in seismic and electromagnetic prospecting for oil in the Po valley.

$\mathrm{He}$ was appointed director of the Geophysical Institute of Trieste in 1920. When the Institute was divided in 1949, ho became director of both the Geophysical Observatory and the Thalassographical Institute. His last years were devoted to preparing a second edition of his book on meteorology, "L'Aria", and to writing a large work on oceanography, "II Mare".

WE regret to announce the following deaths :

Prof. G. D. Hale Carpenter, M.B.E., Hope professor of zoology in the University of Oxford during 193348 , on January 30 , aged seventy.

Prof. J. H. Orton, F.R.S., emeritus professor of zoology, University of Liverpool, and formerly director of the Marine Biological Station, Port Erin. on February 2, aged sixty-eight. 